disease. It was found, however, that although there was amelioration in the condition of the patient in the early stages of the treatment, the drug soon lost its elfect, whilst certain sequelæ, e.g. blindness, the results of the action of the drug, led men to be exceedingly chary of using it. In connection with sleeping sickness, Koch, following up Bruce's theory of a living reservoir in which certain parasites might exist without giving rise to any definite and appreciable disease, instancing the wild buffalo, where the parasite is kept alive in its host without apparently doing any damage, but ready to attack nonimmunised animals when carried to them by the tsetse fly (Glossina morsitans), Koch suggested that the crocodile might be the reservoir host of the trypanosome that gives rise, when carried to the human being by another tsetse fly (Glossina palpalis), to sleeping sickness, and he then made the suggestion, afterwards carried out, that the infective zone around certain waters should be cleared of its underwood, and the crocodiles lurking there and in the neighbouring waters killed. Koch also worked at malaria in Java and in the Malay Peninsula. He studied blackwater fever and tried to determine its relation to malaria, or, alternatively, to quinine poisoning contracted during the treatment of malaria.

Koch's last great public appearance was at the Washington Congress on Tuberculosis in 1908, when he announced that he intended to devote the remaining years of his life to the settling of the question that he had raised in London eight years earlier, and everyone hoped that he had some years of useful work before him. These years have been all too few, and we cannot expect that the work he then undertook is finished.

The record of a man's work is his best obituary notice-and in such a case as that now under consideration the writer is relieved of an enormous responsibility-but this notice would be very incomplete did it not contain some record of the honours accorded to him by his fellows, especially those who followed and appreciated his work. Robert Koch was an honorary member of a very large number of learned assóciations, amongst them of the Prussian Academy and of the Royal Society of London. He had been invested with the Prussian and French Orders of Merit, and with orders of various kinds awarded by the rulers of almost every State in Europe. In some cases these distinctions might mean but little to those who come after us, but, associated with Koch's name, they must ever retain their significance as associated with one of the names on the imperishable roll of the great in science. The death of Robert Koch involves a loss not to Germany only -all mankind is the poorer.

\section{MAJOR PHILIP CARDEW, R.E.}

MAJOR PHILIP CARDEW, whose death we record with deep regret, combined a fine mathematical mind with careful scientific training, and a remarkable natural ability in grasping the principles involved in any practical question. He passed through Woolwich Academy with every honour, and started a brilliant career in the Royal Engineers in $187 \mathrm{I}$. He was appointed, in 1883 , instructor in electricity at the Military School of Engineering at Chatham, and threw himself with great energy into those innumerable electrical problems which were being so rapidly developed in telegraphy, telephony, electric lighting and power. In I 888 he was selected as the first electrical adviser to the Board of Trade, and he inaugurated the rules and regulations for the use of electricity for public supply and for electric tramways and railways. 'These rules have formed a model for all countries, and there is very little doubt that the freedom of water and gas pipes in England from electrolysis due to stray tramway currents is the result of the wise restrictions which Major Cardew initiated. The standardisation of electrical units was part of his work.

When Major Cardew retired from the Board of Trade his energies were diverted into the execution of various lighting, power, and traction schemes. Under his personal guidance, every Government dockyard in the British Empire has been equipped with eléctric power, and numerous electric railways, tramways, and lighting systems originated. $\mathrm{He}$ was a prolific inventor. and his vibrator is largely in use in connection with military telegraphs, while the hot-wire voltmeter which bears his name was for years one of the few trustworthy electrical instruments. The Cardew safety earthing device has also been of great value in connection with the public supply of electricity.

Major Cardew contributed a number of papers on electrical subjects to the Royal Society and the Institution of Electrical Engineers.

His death, at the early age of fifty-eight, is greatly to be regretted. He was intimately associated with all the modern developments of electricity, and his experience and advice were much in demand.

\section{NOTES}

IN consequence of the death of King Edward VII., the usual ladies' conversazione of the Royal Society will not be held this year.

AT a meeting of the council of the Royal Society, held on Thursday, May 26, at Burlington House, an address of condolence and homage to His Majesty King George V. was adopted, and the society's seal affixed. At the ordinary meeting of the society, which followed, the address was communicated to the fellows present by the president, Sir Archibald Geikie, who spoke as follows:- "Since the last meeting of the society a great calamity has unexpectedly befallen the country, and under the shadow of that mournful event we now resume our duties. The death of King Edward is a national loss, the full effect and meaning of which cannot yet be appreciated. We, fellows of the Royal Society, share in the universal sorrow that a life so revered, so full of achievement, and with the promise of still many fruitful years, should have been cut short in its prime. But we have also a more personal ground for regret. The late $\mathrm{King}$ had been for nearly half a century one of our fellows, and on his accession to the throne had become our patron. Among the many claims which His Majesty had to our regard, not the least was the interest which he always took in the furtherance of that natural knowledge which the Royal Society was founded by Charles II. to promote. In our annals the name of King Edward VII. will always hold an honoured place. The council has approved and sealed an address to His Majesty King George V. in which, while expressing our condolence in the deep grief of the Royal Family, we offer our respectful congratulations on his accession to the throne of his ancestors, and our confident hope that his reign may be long and prosperous." The address was then read from the chair, and was adopted in silence, the fellows present all standing.

As we go to press, the Terra Nova is starting on her journey with the British Antarctic Expedition, and, after calling at a number of places, is expected to arrive at Lyttelton, New Zealand, about October 13. Hitherto Antarctic expeditions have sailed to the south in the latter 